XVII Warsztaty Antropologiczne im. Profesora Janusza Charzewskiego Łódź 2016

http://dx.doi.org/10.18778/8088-439-7.02

\title{
CEZARY KUKLO
}

Instytut Historii i Nauk Politycznych, Uniwersytet w Białymstoku

\section{DEMOGRAFII HISTORYCZNEJ WKLAD DO NAUK O RODZINIE}

Jeszcze sto lat temu zainteresowania historyka ograniczano zasadniczo do wąsko pojmowanej historii politycznej, rekonstruującej głównie zdarzenia, których nie wiązano $\mathrm{z}$ całokształtem życia społecznego ${ }^{1}$. Trzeba było dopiero przełomu metodologicznego $\mathrm{w}$ badaniach historycznych, znaczonego powstaniem a później dorobkiem badaczy skupionych wokół francuskiego czasopisma "Annales d'Histoire Economique et Sociale", obecnego od lat 30. XX wieku, którzy zaczęli sięgać po nowe metody i nowe problemy obecne w dorobku innych dyscyplin nauk humanistycznych i społecznych (Iggers 2010). Ujmując jeszcze krócej wspomniany przełom zaowocował z jednej strony interdyscyplinarnością w spojrzeniu nie tyle nawet na pojedynczego człowieka co całe populacje, z drugiej, rozbudową kwestionariusza badawczego oraz - co istotne - unowocześnieniem technik badawczych. Owe charakterystyczne przesunięcia w kierunkach uprawiania historii, bardziej widoczne po II wojnie światowej, nie pozostało bez wpływu dla studiów demograficznych przeszłości. Jak nigdy wcześniej bowiem ludzkość była świadkiem wyludnienia krajów wysoko rozwiniętych i przeludnienia terytoriów słabo rozwiniętych gospodarczo (Poursin 1971; Livi Bacci 1999). Siłą rzeczy pojawiły się pytania nie tylko dotyczące istnienia paradoksalnie współzależności między poziomem rozwoju ekonomicznego a poziomem rozrodczości ale także o sam problem rytmu liczebnego wzrostu ludności w okresie wcześniejszym. Historykowi przypadło zatem w udziale dążenie do rekonstruowania głównych determinantów rozwoju ludzkości, tj. poziomu i rozwoju płodności i umieralności w przeszłości, przy jednoczesnym - i równie ważnym - poszukiwaniu przyczyn tychże zmian i przeobrażeń czy też motywacji trendów rozwojowych.

\footnotetext{
${ }^{1}$ Praca finansowana w ramach programu MNiSzW pod nazwą „Narodowy Program Rozwoju Humanistyki w latach 2013-2018”.
} 
Oznaczało to także nowe badawczo i źródłowo wyzwanie dla dotychczas funkcjonującej nauki demografii historycznej. Jej podstawy jako nauki ukształtowały się w drugiej połowie XIX stulecia i przez całe następne dziesiątki lat w tzw. okresie preklasycznej demografii historycznej (do 1945 r.) interesowano się przede wszystkim szacunkami zaludnienia na podstawie eksploatacji rachunkowości podatkowej, dla XIX wieku także spisów ludności różnej proweniencji, zarówno całych państw jak i węższych zasięgów terytorialnych (parafii, miast a nawet pojedynczych wsi), i w różnych przekrojach chronologicznych (Dupâquier 1984). Trzeba wyraźnie stwierdzić, że w pracach wydanych w Europie przed II wojną światową tylko sporadycznie zajmowano się tendencjami rozwojowymi dawnych populacji (Gieysztorowa 1976).

Położenie zatem nacisku na poznanie nie stanu zaludnienia ale mechanizmów rozwoju ludnościowego i społecznego, tym samym podstawowych jego czynników - płodności małżeńskiej oraz śmiertelności niemowlęcej i dziecięcej, zmusiło demografów i historyków do poszukiwania zarówno nowych metod badawczych, jak i odmiennych od dotychczas eksplorowanych źródeł. Nie trzeba specjalnie przekonywać, że w pierwszych latach powojennych wiedza demografów i historyków dotycząca powstawania i wygasania związków małżeńskich, ich postaw prokreacyjnych, narodzin przeplatanych zgonami $\mathrm{w}$ dobie pre- $\mathrm{i}$ wczesno industrialnej była zdecydowanie więcej niż skromna.

Nowe w demografii historycznej przyszło za sprawą niewielkich rozmiarów książki, dwóch badaczy francuskich, statystyka i demografa Louisa Henry'ego oraz archiwisty Michela Fleury'ego, opublikowanej w 1956 r. (Fleury i Henry 1956). Zaprezentowali w niej dwie metody badawcze bezpośrednio odwołujące się do znanych środowisku historyków źródeł, ale do tej pory wykorzystywanych sporadycznie, najczęściej przez genealogów, a mianowicie kościelnych ksiąg metrykalnych zaślubionych, ochrzczonych i pogrzebów, które przy wszystkich niedokładnościach tegoż źródła umożliwiały obserwację podstawowych faktów demograficznych: małżeństw, urodzeń i zgonów. Ze względu na ograniczone rozmiary artykułu pominiemy ważne $\mathrm{z}$ perspektywy historyka dzieje rejestracji metrykalnej na starym kontynencie łącznie z jej czynnikami źródłotwórczymi, podkreślając wszakże, iż dla niektórych krajów zachowała się ona nawet od połowy XVI stulecia, a niekiedy nawet jeszcze wcześniej. Upowszechnienie obowiązku jej prowadzenia przez duchownych w parafiach nastąpiło w XVII wieku. Jeżeli dodamy do tego że od początku XIX stulecia dysponujemy obok wyznaniowej rejestracji metrykalnej, także państwową statystyką ruchu naturalnego ludności, stało się jasne, że zaistniała możliwość badania przebiegu procesów demograficznych nawet $\mathrm{w}$ stosunkowo odległej przeszłości. Owe przesuniecie punktu ciężkości w dotychczasowych badaniach z szacunków zaludnienia na poznanie dynamiki zaludnienia, jej czynników i jej 
konsekwencji, jakie dokonało się m.in. także za ich sprawą, zaczęto określać okresem klasycznej demografii historycznej.

M. Fleury i L. Henry mieli świadomość zarówno niedoskonałości proponowanej przez nich bazy źródłowej, pracochłonności jej obróbki wreszcie celów badawczych. Dlatego też w swoim historycznym już dzisiaj „podręczniku” zaproponowali dwie metody: agregatywną (nazywaną zamiennie także zbiorczą, sumaryczną lub pobieżnych badań sondażowych) i rekonstrukcji rodzin, nazywana też nominatywną (Fleury i Henry 1956). Dodajmy, że już dwa lata później z treścią owego „podręcznika” zostali zaznajomieni czytelnicy w naszym kraju za sprawą recenzji Józefa Matuszewskiego zamieszczonej na łamach „Roczników Dziejów Społecznych i Gospodarczych”.

Metoda agregatywna jest przede wszystkim metodą anonimową i wybitnie statystyczną, która stosunkowo małym nakładem pracy - nie wymaga bowiem ręcznego przepisywania treści metryk parafialnych na pojedyncze fiszki lub też wprowadzania ich do pamięci komputera, pozwala rozpoznać podstawowe trendy rozwojowe badanej populacji. Jej praktyczne zastosowanie sprowadza się do przeniesienia informacji do $\mathrm{z}$ góry przygotowanych przez badacza tablic, które umożliwiają następnie poznanie następujących zagadnień szczegółowych:

- liczby urodzeń, małżeństw i zgonów w latach kalendarzowych i rolniczych, przy czym dla tych ostatnich przyjmuje się okres od 1 VIII do 31 VII, celem ustaleń korelacji między liczebnością poczęć i efektywnością zbiorów,

- sezonowości miesięcznej poczęć, małżeństw i zgonów,

- częstotliwości urodzeń nieślubnych,

- częstotliwości chrztów dzieci podrzutków,

- częstotliwości pierwszych i następnych małżeństw,

- deklarowanego wieku nowożeńców,

- śmiertelności niemowlęcej,

- wieku i stanu cywilnego osób zmarłych,

- odstępu między zgonem a pogrzebem,

- innych zagadnień np. częstotliwości nazwisk i imion, zawodów.

W późniejszych latach część badaczy ujmowała w tej metodzie także inne zagadnienia jak np. sezonowość tygodniową chrztów, ślubów i pogrzebów, doboru terytorialnego nowożeńców, odstępu między zgonem a pogrzebem czy przyczyn zgonów.

Metodą agregatywną możemy opracowywać rejestrację metrykalną poszczególnych trzech serii nawet niezależnie od siebie, co ma istotne znaczenie biorąc pod uwagę bardzo zróżnicowany jej stan zachowania w różnych krajach we wczesnej dobie nowożytnej, co dobrze widać także na przykładzie Rzeczypospolitej Obojga Narodów. Jednakże chcąc poznać rozmiary umieralności niemowląt (dzieci które nie ukończyły 1 roku życia) na określonym 
terenie, wyrażone współczynnikiem ich umieralności musimy dysponować dwoma seriami metryk z identycznego okresu tj. chrztów i pogrzebów. Co więcej, te ostatniej metryki muszą zawierać informacje o wieku zmarłych dzieci, który na ziemiach polskich na szerszą skalę zaczął być odnotowywany dopiero w drugiej połowie XVIII wieku (Kuklo 2009).

Wspomniana metoda, prosta $\mathrm{w}$ zastosowaniu $\mathrm{i}$ mało pracochłonna, pozwalała na badanie długich trendów rozwoju populacji, nie obejmowała jednakże studiów nad rodnością, wpływającej na tempo przyrostu zaludnienia. Dlatego też francuscy badacze obok niej zaproponowali jeszcze drugie podejście badawcze - nazwane metodą rekonstrukcji rodzin. Najprościej rzecz ujmując polega ona na odtworzeniu losów demograficznych rodzin na podstawie imiennego przyporządkowania parom małżeńskim wszystkich wydarzeń demograficznych ich dotyczących i zebranych na karcie rodziny zrekonstruowanej (Fleury i Henry 1956), zob. ryc. 1. Od strony formalnej wprawdzie nie jest ona skomplikowana, ale też wbrew pozorom nie polega ona li tylko na mechanicznym łączeniu danych, już chociażby ze względu na rozmaitą pisownię imion i nazwisk w metrykach we wczesnym okresie nowożytnym, dobrze widoczne w tym czasie także na ziemiach polskich. Natomiast $\mathrm{z}$ całą pewnością jest bardzo żmudna i pracochłonna, gdyż odtworzenie demograficznych losów rodzin $\mathrm{w}$ populacji paro tysięcznej $\mathrm{w}$ okresie jednego stulecia wymaga eksploracji kilkudziesięciu tysięcy łącznie aktów ślubów, urodzeń i zgonów. Jedną z jej zalet jest możliwość odszukania metryk chrztów samych nowożeńców stających na ślubnym kobiercu i tym samym obliczenie niezmiernie ważnego parametru z perspektywy badań nad płodnością, a mianowicie rzeczywistego wieku kobiety w chwili zamążpójścia. Należy zarazem lojalnie uprzedzić potencjalnych jej użytkowników, że zrekonstruowanie losów demograficznych nawet kilkudziesięciu czy kilkuset rodzin nie zamyka jeszcze postępowania badawczego właściwego owej metodzie. Przed badaczem pozostaje jeszcze - umownie można określić - jej drugi etap, a mianowicie skrupulatne wypełnienie kart rodzin zrekonstruowanych, które umożliwiają przeprowadzenie stosownych obliczeń statystycznych, zob. ryc. 2.

Pomimo wspomnianej pracochłonności jej zastosowanie umożliwia poznanie bardzo wielu szczegółowych zagadnień, choć początkowo zakres jej nie był aż tak mocno rozbudowany:

- rzeczywistego a nie deklarowanego przeciętnego wieku nowożeńców w chwili ślubu według płci i stanu cywilnego,

- kojarzenia się par małżeńskich badanego pod kątem wieku nowożeńców,

- długości trwania małżeństw,

- częstotliwości małżeństw powtórnych,

- doboru społecznego i terytorialnego nowożeńców, 
- długości trwania wdowieństwa,

- ponownych związków małżeńskich według liczby dzieci ze związku poprzedniego,

- liczby dzieci w rodzinie,

- liczby dzieci w rodzinie według wieku aktualnego ojca i matki,

- wieku matki według kolejności urodzenia dzieci,

- rozmiarów poczęć przedślubnych,

- długości przerwy protogenetycznej (między ślubem a urodzeniem pierwszego dziecka),

- długości przerw intergenetycznych (międzyporodowych) według wieku matki i liczby urodzeń,

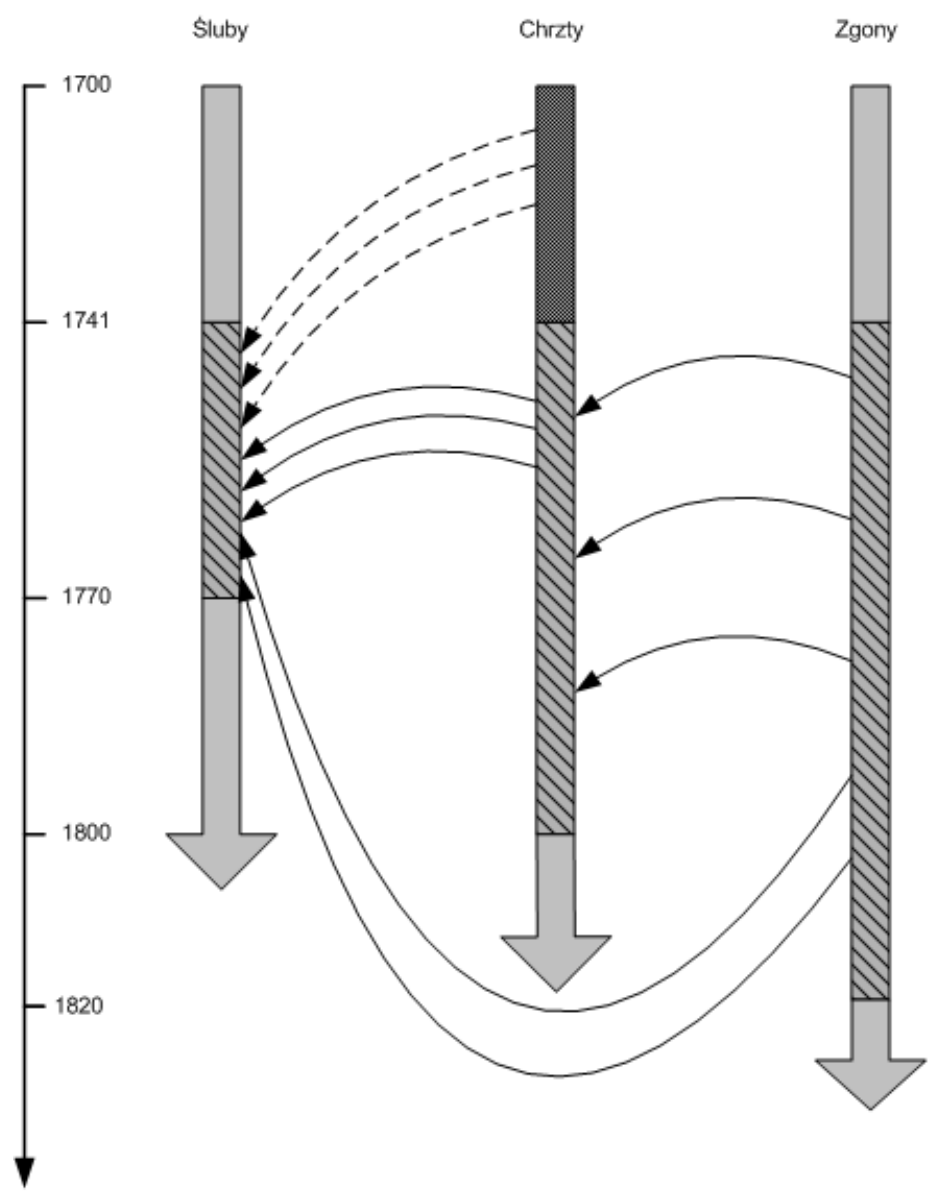

Ryc. 1. Schemat nominatywnego łączenia danych w metodzie rekonstrukcji rodzin. Źródło: opracowanie własne 


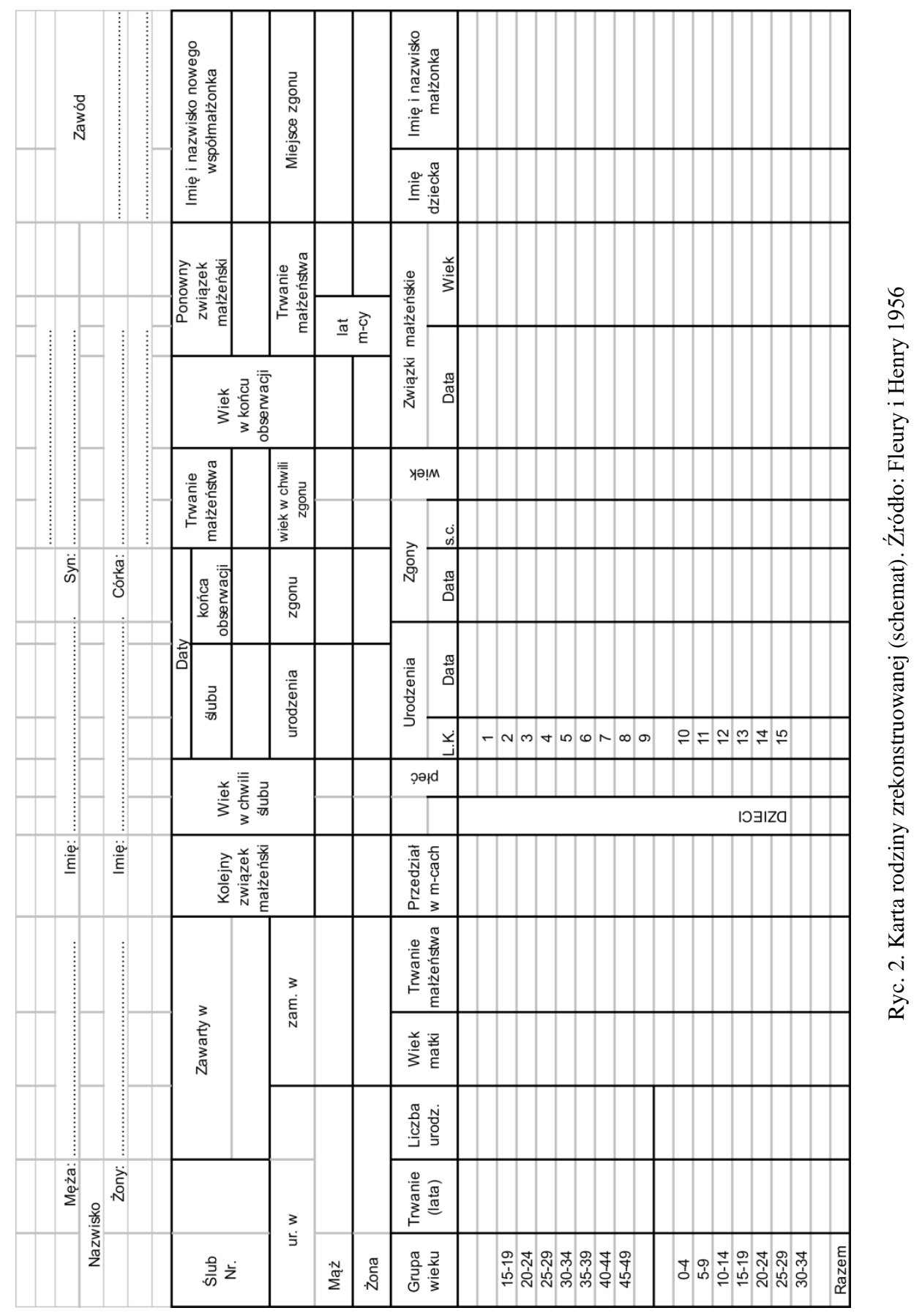


- długości przerw intergenetycznych (międzyporodowych) w zależności od losu poprzedniego dziecka,

- płodności kobiet według wieku matki w chwili ślubu,

- płodności kobiet według długości trwania małżeństwa,

- częstotliwości porodów wielorakich w rodzinie,

- urodzeń wielorakich a zatrzymanie płodności,

- zgonów według płci, wieku i stanu cywilnego,

- zgonów niemowląt w ogólnej liczbie zgonów,

- umieralności niemowląt i dzieci według płci,

- okołoporodowej umieralności kobiet.

Patrząc na program badawczy tej metody z perspektywy ponad półwiecza można powiedzieć o dużej rozległości horyzontów umysłowych jej twórców, którzy zaproponowali prawdziwy mikroskop do analiz struktur demograficznych dawnych rodzin. Dodajmy, co jest istotne, że kolejne podręczniki demografii historycznej już samego autorstwa Louisa Henry’ego, uszczegóławiały i wzbogacały aparat metodologiczno-statystyczny wspomnianej metody (Henry 1967, 1980). Z całą pewnością też swój wkład w poszerzanie kwestionariusza badawczego metody rekonstrukcji rodzin wniósł Jean-Pierre Bardet, wieloletni dyrektor Centre Roland Mousnier Université de Paris IV-Sorbonne. Wspólnie z informatykiem Michaelem Hainsworthem opracował jeden $\mathrm{z}$ najbardziej popularnych, przynajmniej $\mathrm{w}$ środowisku historyków francuskich, program informatycznego przetwarzania danych zarówno z samych ksiąg metrykalnych 3 serii, jak i przede wszystkim rodzin zrekonstruowanych ręcznie (Hainsworth i Bardet 1981). Dużą wartość poznawczą metody rekonstrukcji rodzin zgodnie podkreśla światowa czołówka historyków, ekonomistów i demografów (Kula 1963; Palli 1979; Reher 1979; Borscheid 1980), a głosy krytyczne pojawiają się rzadko (Leti 1979; Akerman i Lockridge 1983). W licznie wydawanych podręcznikach demografii historycznej zajmuje ona niekwestionowane miejsce naczelne (Guillaume i Poussou 1970; Imhof 1977; Maur 1983, Del Panta i Rettaroli 1994; Kuklo 2009).

Tym niemniej zarówno jej twórcy jak i późniejsi użytkownicy zwracali uwagę nie tyle nawet początkowo na dużą jej pracochłonność, która już w połowie lat 70 . minionego stulecia zeszła na plan dalszy wraz z wkroczeniem do warsztatu historyka elektronicznej techniki obliczeniowej, co jej duże wymogi badawcze. Pierwszym - jest równoległe zachowanie ze stosunkowo długiego okresu (najlepiej około stu lat) rejestracji urodzeń i zgonów, i tylko $\mathrm{z}$ trochę krótszego okresu rejestracji małżeństw. Drugim - jak największa kompletność podstawy źródłowej, którego nie docenianie jak się okazało w przyszłości, także w naszym kraju, może prowadzić nawet najbardziej subtelne analizy na manowce. Chcąc uniknąć porażek badawczych które po latach pracy zaowocują rekonstrukcją większości par małżeńskich z dwojgiem 
lub trojgiem urodzonych dzieci, dość szybko wypracowano kryteria służące weryfikacji kompletności rejestracji tj.:

- liczba urodzeń (chrztów) przypadająca na jedno małżeństwo (ślub) $-\mathrm{U} / \mathrm{M}$

- liczba urodzeń (chrztów) przypadająca na jeden zgon (pogrzeb) $-\mathrm{U} / \mathrm{Z}$

- współczynnik maskulinizacji noworodków.

W świetle dotychczasowych ustaleń historiografii międzynarodowej spośród trzech serii metryk ślubów, chrztów i zmarłych pierwsze obciążone są najmniejszymi brakami w stosunku do rzeczywiście zawartych ówcześnie małżeństw. Śluby wyznaniowe w świecie chrześcijańskim do czasów Kodeksu Napoleona zostały uznane za jedyną ważną formę zawarcia małżeństwa i podstawę legalności potomstwa. Toteż wymienione wyżej dwa wskaźniki - U/M i U/Z oraz współczynnik maskulinizacji w grupie noworodków, przy założeniu kompletności ślubów, orientują nas przede wszystkim w brakach w rejestracji chrztów i zmarłych. Do końca epoki późnofeudalnej na względnie poprawnym materiale metrykalnym podanej wyżej kryteria powinny kształtować się na poziomie powyżej 4,5 urodzeń na małżeństwo (z ewentualną korektą w dół w odniesieniu do miast dużych) oraz niewiele ponad 1 urodzenie na zgon, wobec stosunkowo wysokiej ówcześnie umieralności, a co za tym idzie, minimalnym przyroście naturalnym. Trochę bardziej skomplikowana sprawa wygląda ze współczynnikiem maskulinizacji, gdyż jego wzorcową wartość 105-107 urodzonych chłopców na 100 dziewczynek, uznawany za probierz kompletności rejestracji chrztów, daje się obserwować dopiero w wystarczająco dużej zbiorowości ludzi. Henry wskazuje np. że eksplorując 10 tys. metryk chrztów wartość wskaźnika maskulinizacji noworodków powinna zawrzeć się w przedziale 103-107 M $/ 100 \mathrm{~K}$, ale już w wypadku bazy dużo mniejszej, np. z 2,5 tys. urodzeń, jego wartość może sytuować się nawet pomiędzy 101 a 110 M/100 K (Henry 1980).

Zrekonstruowane rodziny dzielą się na dwie zasadnicze grupy. Pierwszą $\mathrm{z}$ nich tworzą rodziny zamknięte, dla których znana jest datę ślubu i zgonu pierwszego małżonka (MF). Drugą natomiast - rodziny otwarte (MO), dla których znana jest data ślubu, ale nie odnaleziono w rejestrach metrykalnych metryki zgonu pierwszego ze współmałżonków. Przy tym ze względu na różne sposoby ustalania wieku kobiety w chwili zawarcia małżeństwa, wśród rodzin zamkniętych wyróżnia się jeszcze trzy podgrupy:

- rodziny, dla których wiek kobiety ustalono na podstawie jej metryki chrztu (MF 1);

- rodziny, dla których wiek kobiety ustalono na podstawie informacji z metryki ślubu lub ze spisu ludności (MF 2);

- rodziny, dla których wieku kobiety nie ustalono (MF 3). 
Z obowiązku dodajmy, że twórca metody Henry dopuszczał rekonstruowanie dziejów rodzin nie dysponując aktem ślubu. Zrekonstruowane w ten sposób rodziny oznaczał symbolem E (wskazując, że ślub miał miejsce w innej niż badana parafia). Także i ta grupa rodzin mogła być zamknięta (EF) lub otwarta (EO).

W analizach dzietności rodzinnej i płodności kobiet największą wartość poznawczą mają bez wątpienia rodziny zamknięte i kompletne zarazem. Przypomnijmy zatem, że rodzinami kompletnymi nazywamy małżeństwa, w których kobieta dożyła wieku kończącego jej zdolność do prokreacji - 49 lat $\mathrm{z}$ tym samym partnerem. Ponieważ metoda rekonstrukcji rodzin bada generacje lub kohorty, które zakończyły swój okres rozrodczy, umożliwia tym samym posłużenie się miernikami stosowanym $\mathrm{w}$ analizie kohortowej. O podstawach teoretycznych analizy kohortowej (wzdłużnej) o raz jej zastosowaniu w obserwacji populacji, także w przeszłości, dobrze informuje zbiorowy tom Analiza kohortowa, m.in. z pracami Louisa Henry'ego, Lucie BurkhardOsadnik, Stanisława Borowskiego (Borowski red. 1976). W tym miejscu warto przypomnieć, że rozrodczość (rodność) i płodność należy do podstawowych kategorii w demografii.

Metoda rekonstrukcji rodzin, którą $\mathrm{w}$ światowej historiografii określana od nazwiska twórcy - metodą Henry, choć nie brak głosów ukazujących podobne prace wprawdzie mniej zaawansowane statystycznie przed ukazaniem się francuskiego podręcznika, bez sprzecznie osiągnęła sukces międzynarodowy, znaczony setkami prac. Nie ulega wątpliwości że jej szerokie zastosowanie we Francji, Anglii, Włoszech, Hiszpanii czy w Niemczech pozwoliło obok głębszej znajomości zjawisk demograficznych, ukazać zróżnicowane postawy prokreacyjne tamtejszych wieśniaków, szlachty i mieszkańców miast, ale także odkryć zwyczaje samoregulujące, pozwalające społeczeństwu Europy Zachodniej przetrwać ewentualne kryzysy (Bardet i Dupâquier eds. 1997-1999; Kuklo 2009). Co więcej, w badaniach nad rodzinami w XIX wieku odwołano się już nie tylko do danych o faktach demograficznych, ale do szeregu innych zaczerpniętych ze źródeł skarbowo-podatkowych, list wyborczych, spisów ludności czy inwentarzy pośmiertnych. Można zatem mówić o ze wszech miar udanym mariażu demografii historycznej z historią społeczną (Żarnowski 2011).

W dużym stopniu dzięki poznaniu dawnych struktur rodzinnych, zarówno tych demograficznych jak i społecznych, ich przeobrażeń i trendów rozwojowych możliwe było powstanie już całych ujęć syntetycznych historii rodziny, autorstwa zarówno zespołów badawczych, jak też i pojedynczych historyków (Burgieuière, Klapisch-Zuber, Segalen i Zonabend eds. 1986; Wrigley, Dawies, Oeppen i Schofield 1997; Kertzer i Barbagli eds. 2001-2002; Gestricht, Krause i Mitterauer 2003). O rozmachu badań z wykorzystaniem metody Henry $\mathrm{w}$ światowej historiografii dobrze orientuje najnowsze opus magnum demografii 
historycznej - A Global History of Historical Demography. Half a Century of Interdisciplinarity, z 37 przekrojowymi artykułami (Fauve-Chamoux, Bolovan i Sogner eds. 2016). Trzeba jednak przyznać, że kondycja demograficzna rodzin późnofeudalnej Europy Środkowej i Wschodniej, zajmuje w nich niewiele miejsca.

Kohortowa analiza płodności zajmuje ważne miejsce w warsztacie badawczym historyka-demografa, choć demografowie współcześni zwracają uwagę na rzadkie ich stosowanie, $\mathrm{z}$ racji wymogu specjalnych badań. O ile analiza poprzeczna koncentruje swoją uwagę na ocenie różnych procesów demograficznych ale $\mathrm{w}$ określonym odcinku czasowym, nierzadko rocznym, o tyle analiza kohortowa wydatnie poszerza możliwości analityczne historyka np. poprzez badanie wpływu całego szeregu zjawisk (kulturowych, społecznych, materialnych) na cykl rodzinny. Co więcej, porównanie kohortowych współczynników płodności w dłuższym okresie np. XVIII-XIX wieku, umożliwia ocenę zmian $\mathrm{w}$ poziomie płodności kobiet, $\mathrm{z}$ jednoczesnym uwzględnieniem wpływu ówczesnych warunków (w szerokim ich ujęciu) na jej kształtowani. Ponadto eliminuje ona wpływ różnic strukturalnych populacji np. wieku. Wspomniane ujęcie kohortowe może być stosowane bezpośrednio do wyznaczania także jeszcze innych, interesujących i wartościowych poznawczo mierników jak np.: badanie rozkładu kolejnych urodzeń według trwania związku małżeńskiego, prawdopodobieństwo powiększania się potomstwa (dla generacji kobiet) lub prawdopodobieństwo powiększania się rodziny (dla kohort małżeńskich).

Rektrospektywne badania nad dziejami demograficznymi rodzin w przeszłości na podstawie rejestrów parafialnych obok odtworzenia intensywności kalendarza płodności umożliwiają zarazem uchwycenie pewnych cech biologicznych płodności m.in. poprzez obserwację odstępów protogenetycznych i intergenetycznych. Ustalenie odstęp czasu między zawarciem małżeństwa a pierwszym urodzeniem pozwala nie tylko na poznanie długości przeciętnego interwału protogenetycznego, ale również na określenie rozmiarów poczęć przedślubnych wśród populacji badanej. W analizach demograficznych za poczęcia przedślubne wśród ogółu urodzeń uznaje się takie, które nastąpiły przed upływem 8 miesięcy od daty zawarcia małżeństwa (0-7 miesięcy). Zestawienie długości odstępów protogenetycznych według wieku matki w chwili zawarcia małżeństwa jest też pomocne przy obserwacji zjawiska płodności kobiet bardzo młodych.

Podobnie zagadnienie długości przerw między kolejnymi urodzeniami (intergenetycznych) stanowi jeden $\mathrm{z}$ ważniejszych elementów, których obserwacja przybliża nam postawy prokreacyjne naszych przodków. Na ogół bowiem panuje przekonanie że nie są one niezależne od jakiejkolwiek chęci kontroli. Wśród elementów wpływających na ich długość niezależnie od praktyk 
społecznych historycy są skłonni wyróżnić m.in.: sposoby odżywiania, zmęczenie fizyczne i psychiczne, częstotliwość stosunków seksualnych, nieumyślne poronienia. W badaniach historyczno-demograficznych obserwację rozkładu odstępów powinno się realizować na podstawie rodzin wielodzietnych, tj. $\mathrm{z}$ sześciorgiem $\mathrm{i}$ więcej potomstwa, $\mathrm{z}$ wyraźnym wskazaniem nie tylko na interwały między pierwszymi dziećmi, ale także na trzy ostatnie. Zmniejszająca się bowiem liczba rodzin wraz $\mathrm{z}$ rosnącą liczbą dzieci powoduje coraz wyraźniejsze zwężenie kręgu badanych matek na korzyść tych, które miały najliczniejsze potomstwo, ale zarazem które charakteryzowały się najkrótszymi odstępami międzyporodowymi. Obliczanie średnich przerw intergenetycznych $\mathrm{w}$ ten sposób prowadziłoby do nadawania ostatnim interwałom wyraźnie krótszych okresów trwania, sugerujących zarazem wzrost płodności $\mathrm{w}$ miarę wzrostu liczby urodzeń, co jest oczywiście nieprawdą. Istotnym fragmentem analiz przerw międzyporodowych jest również obserwacja ich długości według losu poprzedniego dziecka $\mathrm{w}$ dwojakim ujęciu tj. raz $\mathrm{z}$ uwzględnieniem jego śmierci w ciągu pierwszych 12 miesięcy życia, drugi raz przeżycia przez niego wieku niemowlęcego. Wprawdzie w środowisku historyków-demografów trwa spór o wpływ zjawiska karmienia piersią na prawdopodobieństwo ponownego zapłodnienia (Mac Laren 1985), tym niemniej porównanie obu parametrów daje odpowiedź na pytania - czy zgon dziecka w niemowlęctwie odciskał swoje piętno na długości następnej przerwy intergenetycznej.

W końcu metoda rekonstrukcji rodzin pozwala ocenić umieralność dzieci bardziej precyzyjnie niż kiedy dysponujemy tylko statystyką urodzeń i zgonów uporządkowanych według wieku. Ponadto jest możliwe, przynajmniej w przybliżeniu, określenie umieralności jakiejś części osób pozostających w stanie małżeńskim badanej populacji, nawet jeśli jakiś ułamek dat zgonów pozostaje nieznany. $Z$ drugiej strony nie wolno nam zapominać, że umieralność badana na podstawie odtworzonych losów demograficznych rodzin nie obejmuje ani wszystkich przedziałów wiekowych, ani wszystkich stanów cywilnych. Przede wszystkim umyka badaniom umieralność osób stanu wolnego, które nie są już dziećmi i najczęściej nie żyją już razem z rodzicami.

W Polsce pracochłonna metoda Henry'ego przez wiele lat nie znajdowała jakiegoś szerszego odzewu, przede wszystkim z tej racji, że rodzime prace były prowadzone głownie wysiłkiem poszczególnych badaczy, zasadniczo bez poważniejszego zaplecza instytucjonalnego. Z drugiej strony od 1964 r. miejscem przynajmniej prezentacji krajowych doświadczeń w tym zakresie stała się Sekcja (obecnie Zespół) Demografii Historycznej Komitetu Nauk Demograficznych PAN i jej periodyk naukowy - „Przeszłość Demograficzna Polski” (tom 1 ukazał się w 1967 r.). Dodajmy, że sama metoda została zauważona także przez Witolda Kulę, który w swojej syntezie metodologiczno-źródłowej poświęconej historii gospodarczej napisał: „Najdoskonalszą metodą wypracowaną dla 
długofalowych badań demograficznych jest metoda $<<$ rekonstrukcji rodzin $>>$, jedyna metoda dająca na podstawie ksiąg parafialnych rezultaty prawie pewne" (Kula 1963). Z pewnością w czasach PRL-u nie ułatwiało prowadzenie takich badań w oparciu o źródła proweniencji kościelnej, dodatkowo nie zawsze łatwo dostępnych ale i sama problematyka rodzinna nie cieszyła się większym zainteresowaniem środowiska naukowego. Na niepojące zjawisko nieobecności przedstawicieli polskiej nauki w nowoczesnym nurcie światowych badań interdyscyplinarnych poświęconych problematyce rodzinnej $\mathrm{w}$ tam także jej strukturom demograficznym zwracali uwagę tylko nieliczni autorzy (Wyczański 1976; Gieysztorowa 1979; Bogucka 1983).

Przybliżając w największym skrócie rodzime dokonania należy bezsprzecznie przypomnieć dzieło Bohdana Puczyńskiego, ucznia Franciszka Bujaka, powstałe jeszcze przed wojną, a wydobyte z zapomnienia i opublikowane przez Stanisława Borowskiego dopiero ponad trzydzieści lat później (Puczyński 1971 -1974). W studium ludności obejmującym duża parafię rzymskokatolicką kresowego miasta Brzeżany z 24 wsiami i leżącymi na jej terenie 19 parafiami greckokatolickimi w XVII-XVIII w., odnajdujemy cały szereg zagadnień poruszonych w późniejszym podręczniku francuskim, z wyjątkiem płodności. $\mathrm{Na}$ początku lat pięćdziesiątych Stanisław Waszak przedstawił wyniki rekonstrukcji ponad 300 rodzin poznańskich ( $\mathrm{z}$ wykorzystaniem także rejestru pogłównego z 1590 r.) w XVI-początkach XVII wieku (Waszak 1954), zob. aneks I. Obie prace zasadniczo powstały kilka lat wcześniej, jeszcze przed ukazaniem się podręcznika autorstwa Fleury'ego i Henry'ego. W późniejszym okresie wyniki nominatywnych badań metrykalnych zaprezentowała także uczennica Waszaka - Emilia Brodnicka (Brodnicka 1970). Od połowy lat sześćdziesiątych XX w. prowadzono w Akademii Ekonomicznej w Poznaniu pod kierunkiem Stanisława Borowskiego szeroko zakrojone prace nad prokreacją rodzin wielkopolskich od czasów najdawniejszych po współczesne. Niestety, z racji nie zawsze pełnej kompletności chrztów i pogrzebów do końca XVIII stulecia oraz trudności identyfikacyjnych, nie przyniosły one przynajmniej dla epoki preindustrialnej wartościowych rezultatów (Borowski 1978). W sumie zatem do końca lat 70. ubiegłego stulecia ukazały się zaledwie 3 prace z wykorzystaniem metody rekonstrukcji rodzin, w tym aż dwie dotyczące ludności wiejskiej $\mathrm{w}$ dobie przedrozbiorowej, zob. tabela 1 . Powstała ona na podstawie aneksu I, w którym starano się uwzględnić całość rodzimych dokonań na polu analiz dawnych struktur rodzinnych, biorąc za podstawę wyraźną deklarację autorów o zastosowaniu przez nich metody nominatywnej.

Pewien przełom pod tym względem nastąpił dopiero w latach 80. i 90. XX wieku, m.in. za sprawą powołanego do życia przez prof. Andrzeja Wyczańskiego, kilkuosobowego zespołu badawczego historyków i informatyków, pracującego na mocy porozumienia Instytutów Historii PAN w Warszawie i Filii 
Tabela 1. Prace z wykorzystaniem metody rekonstrukcji rodzin w latach 1945-2016

\begin{tabular}{|l|c|c|}
\hline \multicolumn{1}{|c|}{ Lata } & Liczba & W procentach \\
\hline Do końca lat 70. XX & 3 & 10,7 \\
\hline $1981-2000$ & 9 & 32,1 \\
\hline $2001-2016$ & 16 & 57,2 \\
\hline Razem & 28 & 100,0 \\
\hline
\end{tabular}

Źródło: Aneks I.

Uniwersytetu Warszawskiego w Białymstoku, który podjął prace nad informatyzacją rodzimych badań społeczno-demograficznych opartych na rejestrach parafialnych chrztów, opracowywanych metodą L. Henry (Wyczański 1984). $\mathrm{W}$ pracach zespołu, co ważne, wzięli także udział $\mathrm{w}$ roli konsultantów, doświadczeni historycy francuscy wspomniany Jean-Pierre Bardet z ParisSorbonne (Paris IV), autor znakomitego studium poświęconego rodzin preindustrialnego Rouen i Antoinette Fauve-Chamoux z École des Hautes Études en Sciences Sociales w Paryżu, odtwarzającej dzieje najmniejszej komórki socjo-demograficznej w Reims.

$\mathrm{Na}$ tle dotychczasowych bardzo skromnych dokonań, wartościowszego obrazu dzietności małopolskiej rodziny chłopskiej w XVIII-XIX w. dostarczyły studia Edmunda Piaseckiego, realizowane w Zakładzie Antropologii PAN we Wrocławiu, choć trzeba wyraźnie to podkreślić autor nie zastosował w swoich badaniach klasycznej metody Henry'ego, gdyż ich podstawowym celem były aspekty genetyki populacyjnej (Piasecki 1990). Głównym przedstawicielem kierunku propagującego wykorzystanie $\mathrm{w}$ rodzimych badaniach demograficznych wspomnianej metody była przez wiele lat Irena Gieysztorowa, która podjęła żmudny wysiłek odcyfrowania dziesiątków tysięcy starych metryk mieszkańców ziemi łomżyńskiej w XVII-XIX w. Śmierć autorki spowodowała, że ostatecznie zrekonstruowane przez nią rodziny ręcznie nie zostały opracowane pod względem statystycznym i tym samym poznaliśmy jedynie pierwsze bardzo wstępne wyniki (Gieysztorowa 1987). Początek lat 90. XX w. przyniósł cenne wyniki badań nad rodziną w dużych miastach, poznano jej struktury demograficzne $\mathrm{w}$ przedrozbiorowej Warszawie ( $\mathrm{w}$ tym dla parafii św. Krzyża nawet z cząstkowymi współczynnikami płodności) i w stolicy Wielkopolski w I połowie XIX wieku (Kuklo 1991; Makowski 1992; SierockaPośpiech 1992). W tym samym czasie zaczęły się pojawiać także prace związane z powstawaniem rodziny i dzietnością małżeńską na Górnym i Dolnym Śląsku w XVIII-XIX wieku, powstałe pod kierunkiem Zbigniewa Kwaśnego (Uniwersytet Wrocławski), i w ostatnich latach także pod kierunkiem Antoniego Barciaka (Uniwersytet Śląski), tym ciekawsze, że dotyczyły społeczności lokalnych nie tylko katolickich ale i ewangelickich, zob. Aneks I. Pewien wzrost 
ku historii społecznej który dał się zaobserwować w uprawianiu historii w naszym kraju w ostatnich dwóch dekadach zaowocował większym niż do tej pory zainteresowaniem funkcjonowaniem rodziny w przeszłości, w tym także jej struktur demograficznych. Od początku XX wieku daje się zauważyć wyraźny wzrost liczby prac poświęconych najmniejszej komórce demograficznej i społecznej z zastosowaniem metody nominatywnej, co oczywiście cieszy, zob. tabela 1. Jej zawartość wprawdzie ukazuje najlepiej dynamikę w przyroście polskich prac $\mathrm{w}$ tym zakresie, ale też jest świadectwem, jak wiele jeszcze podstawowych wyzwań badawczych pozostaje do zrealizowania w naszym kraju (Kuklo 2015). Większość z prac opublikowanych już w nowym stuleciu koncentruje się głownie na małych miastach oraz parafiach miejsko-wiejskich, o dość jednorodnym obliczu wyznaniowym (katolicy lub ewangelicy). Dlatego w tym miejscu należy podkreślić trud badawczy Agnieszki Zielińskiej, która w swojej niedawno opublikowanej książce zawarła cenne wyniki prac poświęcone dzietności mieszkańców dużego ośrodka miejskiego, jakim był Toruń w XIX wieku, oparte na rekonstrukcji tamtejszych par małżeńskich, żyjących obok siebie społeczności katolickiej, ewangelickiej a nawet kilkudziesięciu rodzin żydowskich (Zielińska 2012).

Przez wiele powojennych lat w polskiej historiografii dominowała opisowa charakterystyka funkcjonowania dawnej rodziny i to zarówno tej żyjącej na wsi (chłopskiej i szlacheckiej, potem ziemiańskiej), jak i w miastach (w XIX wieku często w zróżnicowaniu społecznym). Zwracano w niej uwagę na jej rolę społeczną, socjalizującą, czy gospodarczą praktycznie pozostawiając na boku badanie szczegółowe jej funkcji prokreacyjnej. Ujmując rzecz prościej, na ogół przyjmowano że do końca XIX wieku powstawała ona wcześnie, trwała stosunkowo długo i charakteryzowała się płodnością naturalną. Tymczasem wyniki badań ostatnich lat przyniosły nieco inną, w wielu punktach odmienną charakterystykę kwantytatywnej rodziny polskiej w dobie późno feudalnej i wczesnoindustrialnej. W większości tworzyli ja młodzi ludzie - kobiety dopiero po dwudziestym roku życia i mężczyźni starsi od nich o jakieś 5-7 lat. Małżeństwa w dobie staropolskiej trwały na ogół około 15 lat (dłużej na wsi niż w miastach); w XIX stuleciu nie brak już było związków trwających nawet ponad 20 lat. Badania nominatywne nad rodziną na ziemiach polskich ukazały niemałe rozmiary poczęć przedślubnych, w dużych miastach doby staropolskiej ok. nawet ok. 10-15\%, w okresie następnym jeszcze więcej. Przyniosły one także rzecz najważniejszą a mianowicie charakterystykę postaw prokreacyjnych naszych przodków, dodajmy od razu zróżnicowaną. Zrekonstruowany poziom płodności kobiet może ostrożnie wskazywać, że niektóre pary małżeńskie nie tylko w Warszawie w końcu XVIII wieku, czy w Poznaniu trochę później, ale także na wsi śląskiej już w początkach XIX stulecia, mogły podejmować próby kontroli własnej prokreacji. Zjawisko nie jest jednoznaczne i wymaga $\mathrm{z}$ całą 
pewnością dalszych badań szczegółowych, ale w każdym bądź razie w wielu rodzinach już u schyłku doby staropolskiej i jeszcze wyraźniej w XIX wieku nie widać dążenia do maksymalnego spożytkowania przez zamężne kobiety całego potencjalnego okresu ich zdolności rozrodczych, tj. do 49 roku życia. Wiele mężatek wydaje swoje ostatnie dziecko przed ukończeniem 40 roku życia. Problem badawczym pozostaje nadal ważne zagadnienie wpływu zamożności na rodność. Nie brak głosów, że dostrzegalna źródłowo niższa rodności ubogich wynika $\mathrm{z}$ wyższej umieralności dziecięcej, z reguły słabiej odnotowywanej W rejestracji pogrzebów (zgonów). Z drugiej strony, można mówić o bardziej całościowej ułomności źródeł metrykalnych, przede wszystkim chrztów (urodzeń) i pogrzebów (zgonów) dla tej grupy.

W świetle bogatych zachodnioeuropejskich doświadczeń, jak i coraz liczniejszych rodzimych prób rekonstrukcji rodzin XVII-XIX wieku wynika, że podstawowymi przyczynami porażek są głównie trudności identyfikacyjne oraz niepełność bazy źródłowej. Nie zawsze wczesne wykształcenie się nazwisk na ziemiach polskich, zmienna pisownia przez duchownych parafialnych na dodatek różnych form nazwisk i przezwisk, wielość imion chrzestnych u szlachty i bogatszego mieszczaństwa (nie mówiąc już o magnaterii), pomijanie w metrykach chrztów nazwiska panieńskiego matki, lakoniczność wielu z nich, poprzez pomijanie w ogóle nazwiska rodziców (co jest widoczne zwłaszcza wśród ludności uboższej), nie pozostało bez wpływu na przebieg rekonstrukcji. W naszych problemach identyfikacyjnych nie jesteśmy osamotnieni, czego dowodzą uwagi historyka estońskiego Heldura Palli'ego, powstałe na bazie zastosowania analizy kohortowej do opracowania XVII-XVIII w. tamtejszych metryk (Palli 1976).

Poważnym utrudnieniem jest widoczna aż do połowy XVIII wieku mocno niepełna rejestracja zmarłych dzieci, zwłaszcza niemowląt. Chrzczone $\mathrm{z}$ wody przez rodziców lub akuszerkę tuż przed śmiercią, pochowane bez udziału księdza nie trafiały one do żadnej rejestracji metrykalnej prowadzonej w parafiach, ani ochrzczonych ani zmarłych. Także twórca metody dostrzegł ten problem i w kolejnym podręczniku z 1980 r. zaproponował badanie natężenia płodności małżeńskiej z uwzględnieniem tzw. urodzeń zgubionych (Henry 1980). W końcu w samych metrykach zdarzały się również większe i mniejsze błędy i przemieszania, pochodzące bądź to $\mathrm{z}$ niestaranności, bądź też z pośpiechu autorów rejestracji. Nie ulega też wątpliwości, że duża mobilność terytorialna, widoczna zwłaszcza w odniesieniu do dużych miast staropolskich, wydatnie komplikuje rekonstrukcję rodzin.

W nauce nie ma idealnych instrumentów badawczych, toteż i metoda Henry'ego, obok zasygnalizowanych wyżej trudności w jej stosowaniu, zawiera sama w sobie pewne ograniczenia, o których należy wspomnieć. Przede wszystkim preferuje ona wyraźnie „rodziny zamknięte”, a więc grupy osób, 
które w najmniejszym stopniu charakteryzowały się skłonnością do migracji i mobilności. Przekonali się o tym najpełniej nawet tak doświadczeni badacze, jak historycy z Cambridge Group, którzy z pierwotnie zaplanowanych 404 parafii angielskich do badań nominatywnych, ostatecznie byli w stanie do nich zakwalifikować i zrealizować jedynie 26 parafii (Wrigley i Schofield 1981; Wrigley, Davies, Oeppen i Schofield 1997). Wyłącza tym samym ze szczegółowej mikroanalizy znaczną część rodzin o szczególnej charakterystyce, nie mówiąc już o tym, że poza jej zasięgiem pozostaje grupa ludności trwale bezżennej. Co więcej, z trzech podstawowych determinantów przemian demograficznych - płodności, małżeństwa i umieralności, szczególną wagę nadaje pierwszemu z nich. I wreszcie, wprawdzie teoretycznie nic nie stoi na przeszkodzie jej zastosowana nawet dla wielkich skupisk ludności, to w praktyce jest stosowana głównie do rekonstruowanie dziejów demograficznych społeczności pojedynczych wsi i miast.

Podsumowując, pomimo swojej wielkiej pracochłonności, wysokich wymogów kompletności zapisów metrykalnych oraz innych ograniczeń metoda Henry'ego - rekonstrukcji rodzin - pozostaje bez wątpienia jednym z najważniejszych narzędzi badawczych w warsztacie współczesnego historykademografa. Bezsprzecznie pomaga ona współczesnemu historykowi rozpoznać teoretyczne problemy mechanizmów rozwoju ludności w przeszłości, poprzez obserwacje zachowań prokreacyjnych - w chwili obecnej w skali starego kontynentu - już dziesiątków tysięcy odtworzonych dziejów dawnych rodzin. Warto tu przytoczyć opinię nestora francuskich demografów historycznych Dupâquiera, który przy całym krytycyzmie dla swoich poprzedników nie zawahał się o Henry stwierdzić: „... stworzył wspaniałe narzędzie pracy, będące dla nauk społecznych ekwiwalentem tego, czym jest mikroskop dla nauk biologicznych - narzędziem, którego możliwości wykorzystania w historii i demografii nie zostały jeszcze w pełni odkryte." (Dupâquier 1984) Tym bardziej więc ciągle niedostateczne zastosowanie tej metody w polskiej powojennej nauce historycznej, ograniczone w najlepszym wypadku do niespełna trzydziestu społeczności głównie wsi i małych miast sprawia, że postulat Ireny Gieysztorowej sformułowany przed blisko półwieczem i rozwinięty nie tak dawno przez Cezarego Kuklo ciągle pozostaje aktualny (Gieysztorowa 1976; Kuklo 2015).

$\mathrm{Z}$ drugiej strony nie wolno nam zapominać, że w dobie pre- i wczesnoindustrialnej rodziny biologiczne tj. pary małżeńskie $\mathrm{z}$ dziećmi - główny podmiot zainteresowania metody Henry'ego, zdecydowanie częściej niż współcześnie zamieszkiwały wspólnie z osobami spokrewnionymi i spowinowaconymi, nie mówiąc już o mniej lub bardziej wykwalifikowanej najemnej służbie domowej. Tymczasem wszystkie osoby spoza rodziny nuklearnej we wspomnianej metodzie umykają obserwacji badawczej, podczas gdy ich 
liczebność i struktura współtworzyły potencjał biologiczny rodziny podstawowej i mogły stymulować wiele decyzji i działań gospodarczych, o czym dobrze informuje artykuł autorstwa Michała Kopczyńskiego.

\section{BIBLIOGRAFIA}

Åkerman S., Lockridge K. 1983. Problemy i pułapki historycznych studiów nad zjawiskami demograficznymi. Historyka. Studia Metodologiczne, 13: 3-16.

Bardet J.-P., Dupâquier J. (eds.) 1997-1999. Histoire des populations de l'Europe. T. 1-3. Paris: Fayard.

Bogucka M. 1983. Rodzina w polskim mieście XVI-XVII wieku: wprowadzenie w problematykę. Przegląd Historyczny, 74(3): 495-507.

Borowski S. (red.) 1976. Analiza kohortowa i jej zastosowanie. Warszawa: PWN.

Borowski S. 1978. Prawdopodobieństwo powiększania rodziny w mikroregionie Czacz od XVII do XX wieku. Przeszłość Demograficzna Polski, 10: 135-55.

Borscheid P. 1980. Familie - Wirtschaft - Gesellschaft. Materialen zu einer Socialgeschichte der Familie in Deutschland. AAG Bijdragen, 23: 83-90.

Brodnicka E. 1970. Ludność parafii Wieleń nad Notecia $w$ drugiej połowie XVIII w. Przeszłość Demograficzna Polski, 3: 179-202.

Burguière A., Klapisch-Zuber Ch., Segalen M., Zonabend F. (eds.) 1986. Histoire de la famille. Vol. 1-3. Paris: Armand Colin.

Czop A. 2010. Ruch naturalny ludności parafii juncewskiej w latach 1801-1870 (na podstawie ksiag metrykalnych). Przeszłość Demograficzna Polski, 29: 99-139.

Daszkiewicz-Ordyłowska D. 2001. Rodzina w parafii toszeckiej w latach 1789-1877. Śląskie Studia Demograficzne, 5: 75-109.

Del Panta L., Rettaroli R. 1994. Introduzione alla demografia storica. Roma-Bari: Editori Laterza.

Dupâquier J. 1984. Pour la démographie historique. Paris: Presses Universitaires de France.

Fauve-Chamoux A., Bolovan I., Sogner S. (eds.) 2016. A Global History of Historical Demography. Half a Century of Interdisciplinarity. Bern: Peter Lang.

Fleury M., Henry L. 1956. Des registres paroissiaux à l'histoire de la population. Manuel de dépouillement et d'exploitation de l'état civil ancient. Paris: Éditions de INED.

Gestrich A., Krause J.-U., Mitterauer M. 2003. Geschichte der Familie. Stuttgart: Alfred Kröner Verlag.

Gieysztorowa I. 1976. Wstep do demografii staropolskiej. Warszawa: PWN.

Gieysztorowa I. 1979. Rodzina staropolska w świetle badań demograficznych. Zarys problematyki. Społeczeństwo staropolskie, 2: 159-175.

Gieysztorowa I. 1987. Sprawozdanie z konferencji poświęconej zastosowaniu technik komputerowych $w$ badaniach historyczno-demograficznych XVII i XVIII w. Przeszłość Demograficzna Polski, 17: 265-275.

Górna K. 1987. Analiza demograficzna metryk dolnośląskiej parafii Rząśnik z lat 1794-1874. Przeszłość Demograficzna Polski, 17: 185-205.

Górna K. 2001. Rodzina w parafii Krapkowickiej w XVIII wieku. [w:] Ruchniewicz K., Tyszkiewicz J., Wrzesiński W. (red.) Przełomy w historii. XVI Powszechny Zjazd Historyków Polskich. Wrocław 15-18 września 1999 roku. Pamiętniki. T. 3. Cz. 1. Toruń: Wydawnictwo Adam Marszałek, s. 317-323.

Guillaume P., Poussou J.-P. 1970, Démographie historique, Paris: Armand Colin. 
Guzowski P., Kuklo C., eds. 2015. Studies on family and household in preindustrial Poland. Białystok: Institute for Research of European Cultural Heritage.

Hainsworth M., Bardet J.P. 1981. Logiciel CASOAR. Calculs at analyses sur ordinateurs appliqué aux reconstitutions. Paris: Société de Démographie Historique.

Henry L. 1967. Manuel de démographie historique. Genève-Paris.

Henry L. 1980. Techniques d'analyse en démographie historique. Paris: Éditions de INED.

Iggers GI. 2010. Historiografia XX wieku. Przegląd kierunków badawczych. Tłumaczyła Agnieszka Gadzała. Warszawa: Wydawnictwo Naukowe PWN.

Iluk K. 1998. Ludność parafii Witków Ślaski w latach 1851-1898. Śląskie Studia Demograficzne, 4: 7-62.

Imhof A.E. 1977. Einführung in die Historische Demographie. München: C. H. Beck Verlag.

Kamieniecka A. 2002. Rodzina w parafii katolickiej w Bielawie w latach 1846-1894. Przeszłość Demograficzna Polski, 23: 21-76.

Karbowska J. 2003. Ludność Lubawki w latach 1801-1850. Przeszłość Demograficzna Polski, 24 : $103-154$.

Kertzer D. I., Barbagli M. (eds.) 2001-2002. The History of the European Family. Vol. 1-2. New Haven-London: Yale University Press.

Krotla C. 1991. Ludność parafii bielawskiej w latach 1766-1830 (na podstawie ksiag metrykalnych). Śląski Kwartalnik Historyczny Sobótka, 4: 415-436.

Kuklo C. 1991. Rodzina w osiemnastowiecznej Warszawie. Białystok: Dział Wydawnictw Filii UW w Białymstoku.

Kuklo C. 2009. Demografia Rzeczypospolitej przedrozbiorowej. Warszawa: Wydawnictwo DiG.

Kuklo C. 2015. O potrzebie intensyfikacji badań nad strukturami demograficznymi rodzin na ziemiach polskich do początku XX wieku. Przeszłość Demograficzna Polski, 37(1): 7-36.

Kuklo C. 2016. Polish Historical Demography. Past, Present. Future. [in:] Fauve-Chamoux A., Bolovan I., Sogner S. (eds.) Global History of Historical Demography. Half a Century of Interdisciplinarity. Bern: Peter Lang. 513-532.

Kula W. 1963. Problemy i metody historii gospodarczej. Warszawa: PWN.

Kurowska H. 2010. Gubin i jego mieszkańcy. Studium demograficzne XVII-XIX w. Zielona Góra: Oficyna Wydawnicza Uniwersytetu Zielonogórskiego.

Kwapulińska P. 2001. Rodzina $w$ parafii kochłowickiej $w$ XIX wieku. Śląskie Studia Demograficzne, 5: 111-166.

Leti G. 1979. Problémes d'échantillonage statistique dans les l'enquêtes dedémographie historique. [in:] Marcilio M. L., Charbonneau H. (eds.) Démographie historique, Rouen, Montréal et Paris. Publications de l'Université de Rouen, Les Press de l'Université de Montrél, Press Universitaires de France, pp. 77-107.

Livi Bacci M. 1999. La population dans l'histoire de l'Europe. Paris: Éditions du Seuil.

Mac Laren D. 1985. Marital Fertility and Lactation 1570-1720. [in:] Prior M. (ed.) Women in English Society 1500-1800. London-New York: Methuen, pp. 22-53.

Makowski K. 1992. Rodzina poznańska w I połowie XIX wieku. Poznań: Wydawnictwo Naukowe UAM w Poznaniu.

Maur E. 1983. Základy historické demografie. Praha 1983: Univerzita Karlova (2ed.).

Palli H. 1976. Wstępne opracowanie estońskich materiałów źródłowych do analizy kohortowej. [w:] Borowski S. (red.) Analiza kohortowa i jej zastosowanie. Warszawa: PWN. 245-255.

Palli H. 1979. Kompleksnoje ispolzowanije istocznikow na istoriczeskoj diemografii $w$ XVIII wekie. [in:] Czislenost i klassowyj sostaw nasielenija Rossii i SSR (XVI-XX w.). Tallin: Akademia Nauk Estonskoj SSSR, pp. 148-153. 
Pankiewicz R.I. 2013. Dębowiec - z przeszłości dalekiej i bliskiej. Rodzina, praca i śmierć $w$ świetle ksiag sądowych $i$ metrykalnych (XVIII-XX w.). Krosno-Dębowiec: Pracownia Artystyczno-Reklamowa Apla 3 i Stowarzyszenie Miłośników Dębowca i Okolicy.

Piasecki E. 1990. Ludność parafii bejskiej (woj. kieleckie) $w$ świetle ksiag metrykalnych $z X V I I I-X X w$. Studium demograficzne. Warszawa-Wrocław: PWN.

Poursin J.-M. 1971. La population mundiale. Paris: Éditions du Seuil.

Puczyński B. 1971-1974. Ludność Brzeżan i okolicy w XVII i XVIII w. Przeszłość Demograficzna Polski, 4: 177-214; 5: 15-64; 6: 3-52.

Reher D. S. 1979. Krótki przegląd podstawowych źródet do odtworzenia zaludnienia Hiszpanii $w$ XVI-XIX w. Kwartalnik Historii Kultury Materialnej, 27(3): 375-381.

Rejman S. 2006. Ludność podmiejska Rzeszowa w latach 1784-1880. Studium demograficznohistoryczne. Rzeszów: Wydawnictwo Uniwersytetu Rzeszowskiego.

Ryguła E.M. 2016. Ludność parafii pod wezwaniem św. Mikołaja w Lace w latach 1664-1914 $w$ świetle ksiag metrykalnych. Katowice. Niepublikowana praca doktorska napisana pod kierunkiem prof. dr hab. A. Barciaka.

Rzemieniecki K. 2002. Ludność parafii radzionkowskiej $w$ latach 1801-1850. Przeszłość Demograficzna Polski, 23: 21-76.

Siebel J. 2012. Ludność parafii bogucickiej (województwo śląskie) w latach 1738-1860 (na podstawie ksiag metrykalnych). Katowice: Muzeum Historii Katowic.

Siennicka M. 1998. Rodzina burżuazji warszawskiej i jej obyczaj. Druga połowa XIX i poczatek XX wieku. Warszawa: Wydawnictwo DiG.

Sierocka-Pośpiech M. 1992. L'image démographique de la famille en Vieille Varsovie au déclin du XVIe et XVIIe siècles. [in:] Kuklo C. (ed.) Les modèles familiaux en Europe aux XVIe -XVIIIe siècles. Białystok: Éditions de la Filiale de l'Université de Varsovie à Białystok, pp. $95-101$.

Skierska J. 2015. Ludność Zielonej Góry w latach 1652-1766 w świetle ksiag metrykalnych. Zielona Góra: Oficyna Wydawnicza Uniwersytetu Zielonogórskiego.

Spychała J. 2001. Rodzina w parafii Strzelce Opolskie w latach 1766-1870. Śląskie Studia Demograficzne, 5: 7-74.

Waszak S. 1954. Dzietność rodziny mieszczańskiej i ruch naturalny ludności miasta Poznania w końcu XVI i w XVII wieku. Roczniki Dziejów Społecznych i Gospodarczych, 16: 316-384.

Wrigley E. A., Davies R. S., Oeppen J. E., Schofield R. S. 1997. English population history from family reconstitution 1580-1837. Cambridge: Cambridge University Press.

Wrigley E. A., Schofield R. S. 1981. The Population History of England 1541-1871: A Reconstruction. London: Cambridge University Press.

Wyczański A. 1976. Przedmowa. [w:] Społeczeństwo staropolskie, 1: 3-9.

Wyczański A. 1984. Informacja o pracach zespotu nad systemem informatycznym dla badań społeczno-demograficznych. Przeszłość Demograficzna Polski, 15: 151-153.

Zielińska A. 2012. Przemiany struktur demograficznych w Toruniu w XIX i na początku XX wieku. Toruń: Wydawnictwo Adam Marszałek.

Żarnowski J. 2011. Historia spoleczna. Metodologia - ewolucja - perspektywy. Warszawa: Wydawnictwo Neriton i Instytut Historii PAN (= Metamorfozy społeczne, t. 3).

Żmijewska M. 2007. Ludność parafii tyskiej od 1749 roku do połowy XIX wieku w świetle ksiag metrykalnych. Studium demograficzno-społeczne. Katowice. Niepublikowana praca doktorska napisana pod kierunkiem prof. dr hab. A. Barciaka. 


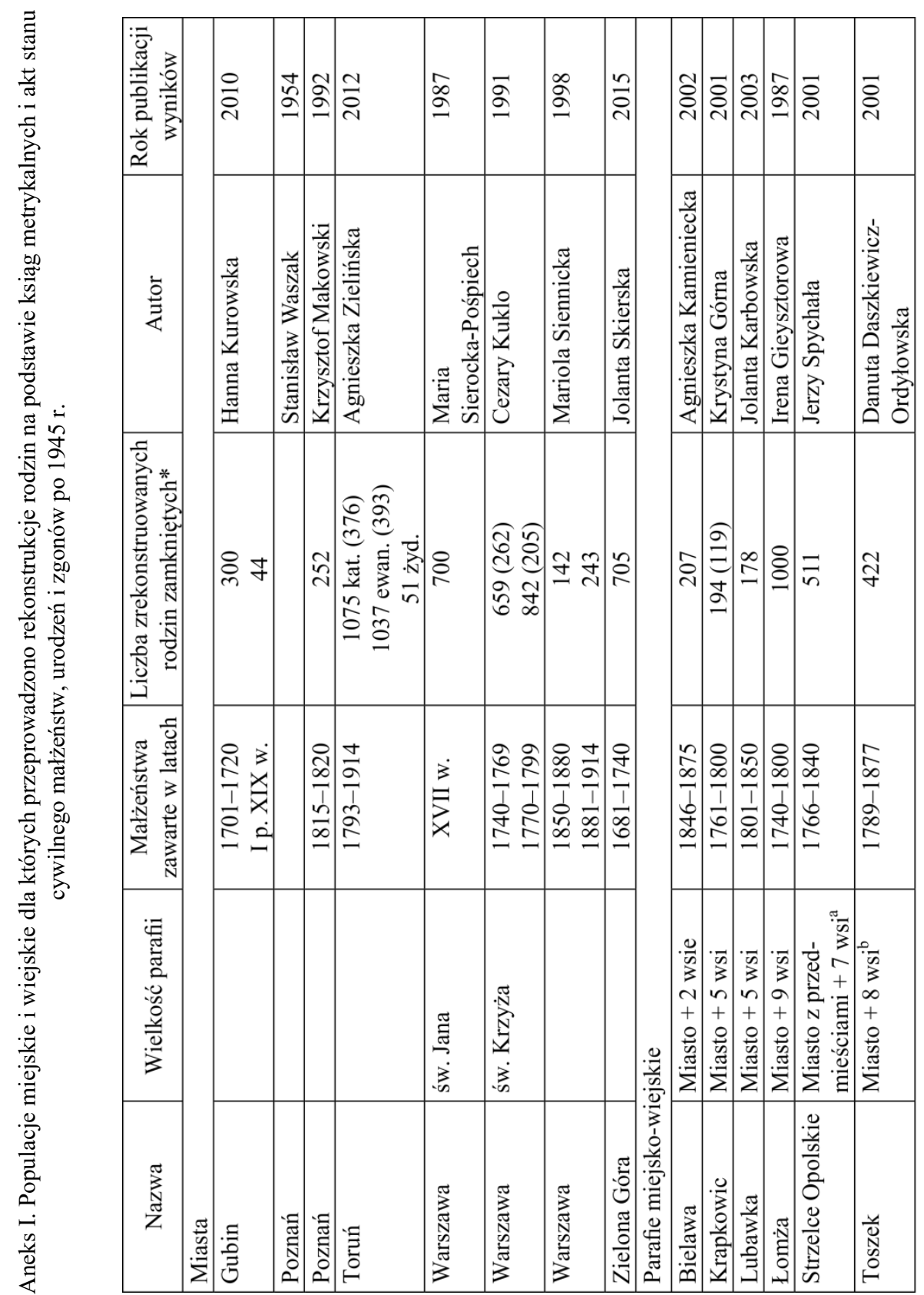




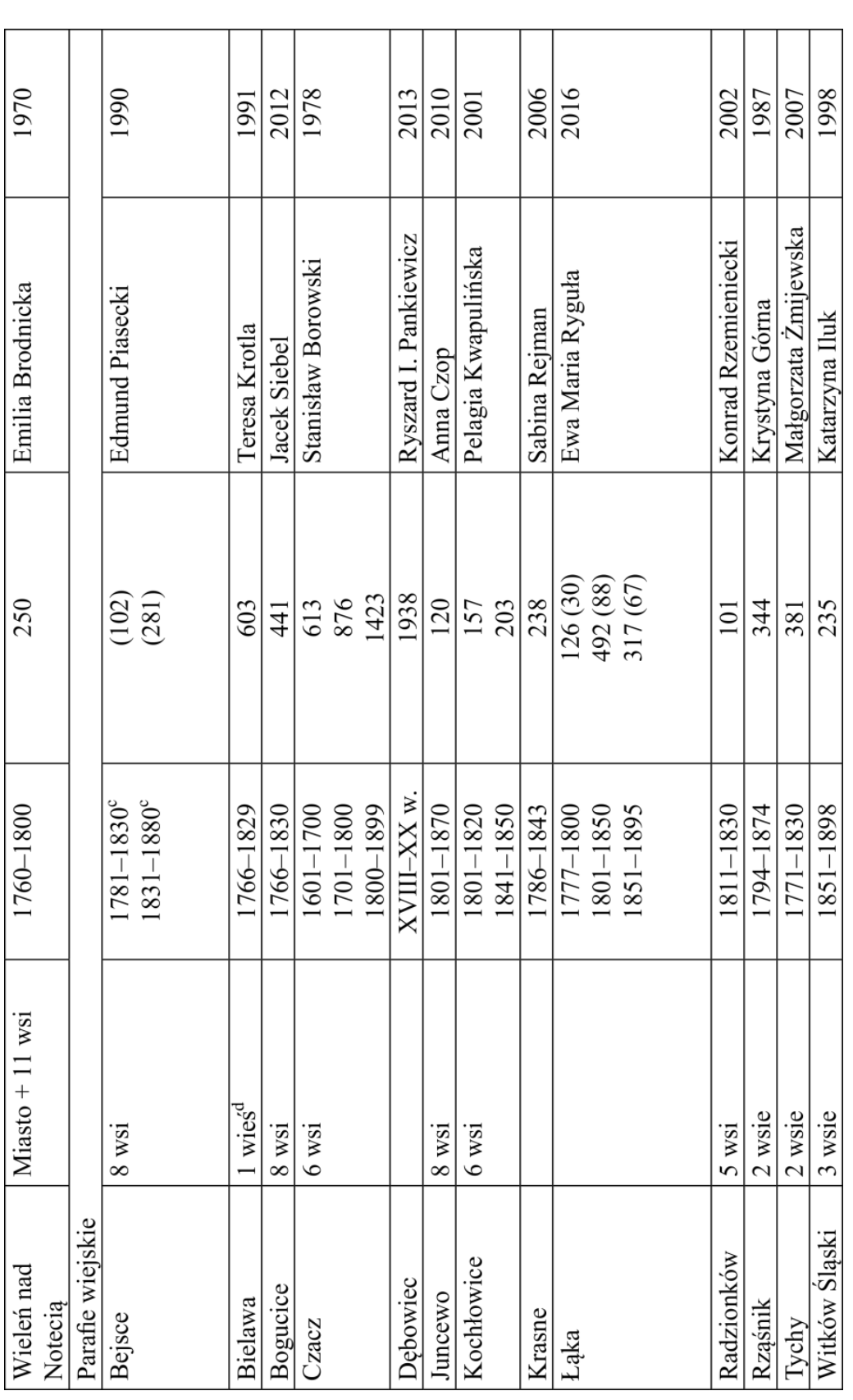

$\frac{\text { 긍 }}{2}$

in

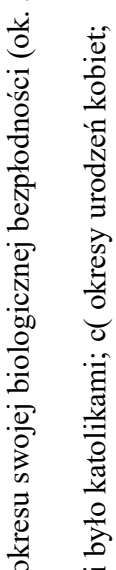

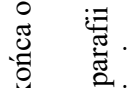

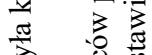

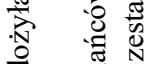

苟

용 है

ठ

递逍

$3 \stackrel{\circ}{\circ}$

:

胥

म

of

空

还

亏 है

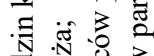
○ ฮี

름

응

에요.

ग्ठ ठ ठे

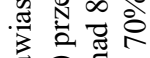

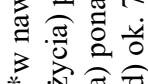

